\title{
Pengaruh Model Pembelajaran Kooperatif Tipe STAD terhadap Keterampilan Sosial dan Hasil Belajar Kognitif Siswa
}

\author{
${ }^{1}$ Dorkas Wini Ngailo, ${ }^{2}$ Agus Muliadi, ${ }^{2}$ Siti Rabiatul Adawiyah, ${ }^{2 \star}$ Taufik Samsuri, \\ ${ }^{3}$ Armansyah \\ ${ }^{1}$ SD Negeri Loko Kalada, Sumba Barat Daya, Nusa Tenggara Timur, Indonesia \\ ${ }^{2}$ Program Studi Pendidikan Biologi, FSTT, Universitas Pendidikan Mandalika, Jl. Pemuda \\ No. 59A Mataram, 83125, Indonesia \\ ${ }^{3}$ Akademi Komunitas Olat Maras (AKOM), Sumbawa Regency, Nusa Tenggara Barat, \\ 84316, Indonesia
}

*Email Korespondensi: taufiksamsuri@undikma.ac.id

\begin{abstract}
Abstrak
Tujuan penelitian ini adalah mendeskripsikan keterampilan sosial dan hasil belajar siswa setelah pembelajaran menggunakan model pembelajaran kooperatif tipe (STAD). Posttest control group design digunakan dalam penelitian eksperimen semu ini. Sampel penelitian ini adalah kelas VII A (kelompok eksperimen) dan kelas B (kelompok control) yang dipilih menggunakan teknik purposive sampling. Instrumen yang digunakan dalam penelitian ini adalah lembar observasi keterlaksanaan RPP, lembar observasi keterampilan sosial, tes hasil belajar kognitif siswa dan lembar validasi soal. Data hasil penelitian dianalisis secara deskriptif dan statistic menggunakan uji-t. Hasil penelitian menunjukkan keterampilan sosial kelompok eksperimen dan kelompok control berkategori baik. Hasil uji statistic menunjukkan bahwa tidak terdapat perbedaan signifikan antara kelompok eksperimen dengan kelompok control (thitung= 1,53 < tabel= 1,93) meskipun secara deskriptif skor rata-rata hasil belajar kelompok eksperimen lebih baik dari kelompok control (mean=63,75 vs. mean=50,52). Penelitian ini menyimpulkan bahwa tidak ada pengaruh signifikan model pembelajaran kooperatif tipe STAD terhadap keterampilan sosial dan hasil belajar kognitif siswa.
\end{abstract}

Kata kunci: Pembelajaran Kooperatif; STAD; Keterampilan Sosial; Hasil Belajar Kognitif

\section{The Effect of the STAD Type Cooperative Learning Model on Students' Social Skills and Cognitive Learning Outcomes}

\begin{abstract}
The purpose of this study was to describe social skills and student learning outcomes after learning using the STAD type cooperative learning model. Posttest control group design was used in this quasi-experimental research. The samples of this study were class VII A (experimental group) and class B (control group) which were selected using purposive sampling technique. The instruments used in this study were the lesson plan implementation observation sheet, social skills observation sheet, student cognitive learning outcomes test and question validation sheets. The research data were analyzed descriptively and statistically using t-test. The results showed that the social skills of the experimental group and the control group were categorized as good. The results of the statistical test showed that there was no significant difference between the experimental group and the control group $\left(t_{\text {count }}=1.53<t_{\text {table }}=\right.$ 1.93) although descriptively the average score of the experimental group's learning outcomes was better than the control group (mean=63.75 vs. mean =50.52). This study concludes that there is no significant effect of the STAD type cooperative learning model on social skills and students' cognitive learning outcomes.
\end{abstract}

Keywords: Cooperative Learning; STAD; Social Skills; Cognitive Learning Outcomes

How to Cite: Ngailo, D. W., Muliadi, A., Adawiyah, S. R., Samsuri, T., \& Armansyah, A. (2021). Pengaruh Model Pembelajaran Kooperatif Tipe STAD terhadap Keterampilan Sosial dan Hasil Belajar Kognitif Siswa. Empiricism Journal, 2(1), 19-28. https://doi.org/10.36312/ej.v2i1.583

https://doi.org/10.36312/ej.v2i1.583

Copyright $(2021$, Ngailo et al This is an open-access article under the CC-BY-SA License.

\section{PENDAHULUAN}

Upaya peningkatan mutu pendidikan sudah sejak lama menjadi komitmen depertemen pendidikan nasional. Upaya nyata yang dilakukan pemerintah untuk meningkatkan mutu pendidikan adalah dengan menyempurnahkan kurikulum, pengadaan bahan belajar, 
peningkatan mutu guru, dan pengadaan fasilitas belajar (Kemendikbud, 2014). Namun masih banyak ditemukan kendala dalam proses pembelajaran seperti pembelajaran yang berpusat pada guru yang membuat minimnya aktivitas siswa dalam pembelajaran (Ningrat, 2018) yang ditunjukkan kurang oleh sikap siswa yang kurang antusias, kurang memperhatikan penjelasan guru, tidak kooperatif saat mengerjakan tugas kelompok, dan minim interaksi antar siswa saat dilakukan diskusi kelompok (Marheni et al., 2020) tidak terkecuali pada mata pelajaran biologi sehingga berdampak pula pada motivasi belajar siswa (Tendrita \& Sari, 2020). Kondisi tersebut kontradiktif terhadap tuntutan pembelajaran abad 21 yang menekankan diantaranya keterampilan kolaborasi dan kecakapan kognitif (Muhali et al., 2020) yang dalam penelitian ini adalah keterampilan social dan hasil belajar kognitif.

Keterampilan social merupakan salah satu keterampilan penting pada abad-21 (Scott, 2015) yang merupakan perilaku siswa berupa interaksi sosial dan partisipasi siswa dengan lingkungannya melalui (Qurtubhi, 2017). Ketrampilan social memiliki tiga aspek penitng yaitu (1) manajemen diri (emosi, berbagi, menghargai), (2) akademis (membantu, berpendapat, menerima pendapat), dan (3) kepatuhan (bersungguh-sungguh) (Maryani, 2011). Keterampilan sosial berfungsi untuk mengkonstruksi personal serta karakter siswa yang berpengaruh pada kemampuan akademik kreativitas siswa. Sayangnya, pada konteks pembelajaran di kelas, guru cenderung mengabaikan pengajaran keterampilan social (Kholin et al., 2016). Penyataan tersebut diperkuat hasil observasi yang dilakukan di siswa kelas VII SMP Negeri 3 Mataram menunjukkan bahwa hasil belajar yang dicapai siswa dalam pembelajaran IPA khususnya biologi masih belum mencapai standar yang diinginkan. Hal tersebut terlihat dari ketuntasan klasikal siswa di empat kelas tidak tercapai $(<85 \%)$. Hal tersebut menunjukkan bahwa siswa mengalami kesulitan belajar dan disinyalir menjadi penghambat tercapainya kriteria ketuntasan minimal (KKM). Hasil wawancara dengan guru juga mengindikasikan permasalahan serupa dengan hasil kajian empiris sebelumnya. Guru lebih dominan menggunakan model ceramah dan model pembelajaran yang kurang sesuai dengan materi yang diajarkan. Kondisi tersebut membuat siswa kurang termotivasi pada saat proses pembelajaran berlangsung, mudah bosan, mengatuk, bermain dengan temantemannya dan lain-lain. Siswa hanya mencatat apa yang di sampaikan oleh guru, sehingga tujuan pembelajaran yang ingin dicapai belum sesuai dengan apa yang diharapkan. Hal ini berpengaruh terhadap keterampilan sosial dan hasil belajar kognitif siswa (Putri et al., 2019). Hal tersebut diperkuat oleh fakta di lapangan yaitu sering terjadi perkelahian antara siswa yang disebabkan oleh kurangnya rasa menghargai dan membuktikan rendahnya keterampilan sosial siswa.

Upaya yang dapat dilakukan untuk mengatasi masalah tersebut salahsatunya adalah dengan menerapkan model pembelajaran kooperatif (Putri et al., 2019) tipe Student Teams Achievement Division (STAD) (Prasetyo, 2020) yang memiliki karakteristik penekanan pada keterampilan sosial siswa. Model pembelajaran kooperatif tipe STAD memiliki langakahlangakah (1) penyampaian tujuan dan motivasi; (2) pembagian kelompok; (3) presentasi dari guru; (4) kegiatan belajar dalam tim (kerja tim); (5) kuis (evaluasi; (6) penghargaan prestasi tim (Rusman, 2011). Hasil penelitian sebelumnya menunjukkan model pembelajaran kooperatif tipe STAD berpengaruh signifikan terhadap keterampilan proses sains (Sari et al., 2015) dan hasil belajar (Alfiani \& Sopiyani, 2014) aktivitas belajar (Prasetyo, 2020). Hasil berbeda juga ditemukan tidak terdapat pengaruh signifikan model pembelajaran kooperatif tipe STAD terhadap berpikir kritis (Arifin, 2018). Sayangnya, hasil peneltian tersebut dilaksanakan pada siswa SMA, SD, dan perguruan tinggi dan pada pembelajaran yang berbeda, sehingga penelitian ini bertujuan untuk mendeskripsikan pengaruh model pembelajaran kooperatif tipe STAD terhadap keterampilan social dan hasil belajar siswa kelas VII SMP Negeri 3 Mataram.

\section{METODE}

Jenis penelitian yang digunakan dalam penelitian ini adalah eksperimen semu karena prosedur penelitian ini dilakukan untuk mengungkapkan hubungan sebab akibat antara variabel yang manipulative (bebas) terhadap variabel respon (terikat) (Arikunto, 2013). Variabel bebas dalam penelitian ini adalah pembelajaran Student Teams Achievement Divisions sedangkan variabel terikat yaitu keterampilan sosial dan hasil belajar kognitif siswa. 
Posttest only control group design (Sugiyono, 2019) digunakan sebagai desain penelitian ini seperti disajikan pada Tabel 1 di mana, $X$ = pembelajaran dengan model pembelajaran STAD; $\mathrm{Y}=$ pembelajaran dengan model Konvensional; $\mathrm{O}_{2}=$ Posttest kelas eksperimen; dan $\mathrm{O}_{4}=$ Posttest kelas control.

Table 1. Posttest only control group design

\begin{tabular}{ccc}
\hline Kelas & Perlakuan & Post test \\
\hline Eksperimen & $\mathrm{X}$ & $\mathrm{O}_{2}$ \\
Kontrol & $\mathrm{Y}$ & $\mathrm{O}_{4}$ \\
\hline
\end{tabular}

Berdasarkan desain penelitian pada Table 1, kelompok kontrol adalah kelas yang digunakan sebagai sampel penelitian yang diajarkan dengan metode ceramah, sedangkan kelompok eksperimen adalah kelas yang digunakan sebagai sampel penelitian yang diberikan perlakuan menggunakan model pembelajarankooperatif tipe STAD pada saat proses pembelajaran. Data akhir didapatkan dari pemberian post-test pada kedua sampel baik kelompok kontrol maupun kelompok eksperimen.

\section{Sampel Penelitian}

Populasi dalam penelitian ini adalah semua siswa kelas VII SMP Negeri 3 Mataram Tahun pelajaran 2017/2018 yang berjumlah 114 siswa yang terbagi dalam 4 kelas yaitu kelas VII A (28 siswa), kelas VII B (29 siswa), Kelas VII C (28 Siswa), dan Kelas VII D (29 Siswa). Sampel dalam penelitian ini adalah kelas VII A dan kelas VIIB yang ditentukan dengan teknik Purposive Sampling. Hal ini disebabkan kedua kelas tersebut memiliki kemampuan hasil belajar yang hampir sama (homogen). Kelas VIIA digunakan sebagai kelompok eksperimen dan kelas VII B sebagai kelompok kontrol.

\section{Instrumen dan Prosedur Penelitian}

\section{Lembar Observasi Keterlaksanaan RPP}

Lembar Observasi Keterlaksanaan pembelajaran adalah instrument yang digunakan untuk mengukur atau memperoleh data keterlaksanaan pembelajaran atau suatu kegiatan yang dirancang oleh peneliti kemudian diamati pada proses pembelajaran. Kegiatan yang dilakukan terkait dengan keterlaksanaan RPP yakni yang dilihat keterlaksanaan pembelajaran apakah sudah sesuai dengan RPP (Rencana Pelaksanaan Pembelajaran) atau tidak. Hasil observasi dicatat pada lembar observasi yang sudah ditentukan, ini adalah kegiatan guru dari awal sampai akhir pembelajaran. Dua orang bertindak sebagai observer yang mengamati dan mendapatkan data keterlaksanaan RPP, dan keterampilan sosial selama proses pembelajaran berlangsung

\section{Lembar Ketermpilan Sosial}

Instrumen ini digunakan untuk menilai atau mengukur keterampilan sosial siswa selama proses pembelajaran berlangsung di dalam kelas. Lembar observasi ini memuat kriteria keterampilan siswa yang harus dimiliki oleh siswa, misalnya tingkah laku siswa pada waktu belajar, tingkah laku siswa pada saat diskusi kelompok, dan partisipasi siswa dalam mengerjakan tugas.

\section{Tes Hasil Belajar Kognitif}

Lembar tes digunakan dalam penelitian ini untuk mengukur data mengenai hasil belajar kognitif siswa pada kelompok eksperimen dan kelompok kontrol. Tes ini berisikan soal-soal yang berkaitan dengan materi yang diajarkan menggunakan Buku Paket ilmu Pengetahuan Alam SMP/MTS Kelas VII Semester 2. Sebanyak 20 butir tes berbentuk pilihan ganda yang diambil dari referensi yang relevan dan diambil dari buku paket Biologi dan dibuat berdasarkan materi dengan tujuan untuk mengetahui ketercapaian siswa dalam menguasai materi yang telah diajarkan. 


\section{Lembar Validasi soal}

Lembar validasi soal ini digunakan untuk mendapatkan data mengenai kualitas soal. Soal yang disusun diberikan kepada dua validator untuk memberikan penilaian terhadap soal yang telah dirumuskan tersebut.

\section{Teknik Analisi Data}

\section{Data Keterlaksanaan RPP}

Analisis data keterlaksanaan RPP yang diukur menggunakan lembar observasi. Dianalisis menggunakan Persamaan 1.

$\%$ Keterlaksanaan RPP $=\frac{\sum \text { Aspek keterlaksanaan }}{\sum \text { aspek } y \text { ang diamati }} \times 100 \%$

Hasil analisis deskriptif keterlaksanaan RPP dikategorisaikan menggunakan Tabel 2. Tabel 2. Kriteria Penilaian Keterlaksanaan RPP (Sugiyono, 2019).

\begin{tabular}{lcc}
\hline No & Persentase (\%) & Kategori \\
\hline 1 & $80-100$ & Sangat baik \\
2 & $60-79$ & Baik \\
3 & $40-59$ & Cukup baik \\
4 & $20-39$ & Kurang baik \\
5 & $0-19$ & Tidak baik \\
\hline
\end{tabular}

\section{Data Keterampilan Sosial}

Analisis data keterampilan sosial yang diperoleh menggunakan lembar observasi keterampilan sosial siswa, dilakukan menggunakan Persamaan 2.

$\mathrm{P}=\frac{A}{B} \times 100 \%$

Di mana $\mathrm{P}=\%$ tingkat keterampilan sosial siswa; $\mathrm{A}=$ Jumlah skor keterampilan sosial siswa yang Nampak; $B$ = Jumlah skor seluruh keterampilan sosial siswa. Hasil penskoran selanjutnya dikategorikan menggunakan pedoman pada Tabel 3.

Tabel 3. Kriteria Penilaian Keterampilan Sosial Siswa (Arikunto, 2013)

\begin{tabular}{cc}
\hline Peresentase (\%) & Kategori \\
\hline $81-100$ & Sangat Baik \\
$61-80$ & Baik \\
$41-60$ & Cukup Baik \\
$21-40$ & Kurang Baik \\
$0-20$ & Tidak Baik
\end{tabular}

\section{Data Validasi Soal}

Pengujian kelayakan soal diketahui dengan mencari rata-rata skor yang diberikan dua validator. Hasil penilaian yang diperoleh dikonversikan ke dalam Tabel 4.

Tabel 4. Pedoman Konversi Kualifikasi Validitas Soal (Asy'ari et al., 2019)

$\begin{array}{cc}\text { Skala Penilaian } & \text { Kategori } \\ <3,52 & \text { Layak } \\ 3,51-2,72 & \text { Cukup Layak } \\ 2,71-1,86 & \text { Kurang layak } \\ \leq 1,86 & \text { Tidak Layak }\end{array}$

\section{Data Tes Hasil Belajar Kognitif}

Data hasil belajar kognitif siswa diperoleh melalui tes hasil belajar. Nilai hasil belajar siswa dihitung dengan Persamaan 3. 
$\mathrm{NA}=\frac{\text { Skor yang diperoleh }}{\text { Skormaksimal }} \times 100$

\section{Uji statistik}

Uji statistic diawali dengan melakukan uji normalitas data. Tujuan dari uji normalitas adalah untuk megetahui apakah ada data post-test atau kemampuan akhir siswa pada kedua kelas berasal dari populasi normal atau tidak. Uji normalitas pada penelitian ini menggunakan rumus Chi-kuadrat (Persamaan 4).

$$
x^{2}=\sum_{i=1}^{k} \frac{\left(f_{0}-f_{h}\right)^{2}}{f_{h}}
$$

Di mana $x^{2}=$ Harga Chi-kuadrat, $f_{0}$ : Frekuensi data hasil observasi; $f_{h}=$ Frekuensi yang diharapkan; dan $k=$ Banyaknya kelas interval. Penguji normalitas dengan Chi-kuadrat memiliki kriteria pengujian, jika $X^{2}$ hitung $\leq x^{2}$ tabel pada taraf signifikan $5 \%$ maka distribusi data nilai hasil belajar (posttes) dinyatakan berdistribusi secara normal. Sedangkan jika $x^{2}$ hitung $\geq x^{2}$ tabel maka dinyatakan tidak terdistribusi secara normal.

Uji homogenitas dilakukan untuk mengetahui apakah kedua data yang digunakan dalam penelitian ini homogeny atau tidak homogeny (Sugiyono, 2019). Pengujian homogenitas data menggunakan uji - $\mathrm{F}$ (Persamaan 5)

$\mathrm{F}=\frac{\text { varians terbesar }}{\text { varians terkecil }} \times 100$

Uji hipotesis dilakukan setelah uji prasyarat (uji normalitas dan homogenitas) data terpenuhi untuk mengetahui pengaruh model pembelajaran kooperatif tipe STAD terhadap hasil belajar kognitif siswa. Jika varians tidak homogen maka uji-t dengan separated varians dengan Persamaan 6 digunakan. Jika varians homogen maka digunakan rumus $t$-tes seperti ditunjukkan Persamaan 7.

$$
\begin{aligned}
& t=\frac{\bar{x}_{1}-\bar{x}_{2}}{\sqrt{\frac{\mathrm{s} 1^{2}}{\mathrm{n} 1}}+\sqrt{\frac{\mathrm{s} 2^{2}}{\mathrm{n} 2}}} \\
& t=\frac{\overline{X_{1}}-\overline{X_{2}}}{\sqrt{\frac{\left(n_{1}-1\right) S_{1}^{2}+\left(n_{2}-1\right) S_{2}^{2}}{n_{1}+n_{2}-2}\left(\frac{1}{n_{1}}+\frac{1}{n_{2}}\right)}}
\end{aligned}
$$

Jika $t_{\text {hitung }}>t_{\text {tabel }}$ pada taraf signifikan $5 \%$, maka hipotesis Ho ditolak artiya ada pengaruh model pembelajaran kooperatif tipe STAD terhadap keterampilan sosial dan hasil belajar kognitif siswa, namun jika thitung $<$ pada taraf signifikan 5\% maka hipotesis Ho diterima artinya tidak ada pengaruh model pembelajaran kooperatif tipe STAD terhadap keterampilan sosial dan hasil belajar kognitif siswa.

\section{HASIL DAN PEMBAHASAN}

Validitas Instrumen Tes

Validasi soal dilakukan oleh dua ahli menggunakan isntrumen validasi. Hasil validasi instrument tes hasil belajar disajikan pada Table 5.

Tabel 5. Hasil Validasi Instrumen Tes

\begin{tabular}{lcccc}
\hline \multicolumn{1}{c}{ Aspek } & Rata-rata validator I & Kategori & Rata-rata validator II & Kategori \\
\hline Isi & 3,5 & Cukup layak & 4 & Layak \\
Bahasa & 2,6 & Cukup Layak & 4 & Layak \\
Konstruk & 3,05 & Cukup Layak & 3 & Layak \\
\hline Rata-Rata & 3,05 & Cukup Layak & 3,66 & Layak \\
\hline
\end{tabular}


Berdasarkan Tabel 5 diketahui bahwa instrument tes hasil belajar kognitif yang digunakan dalam penelitian ini dikategorikan layak berdasarkan skor yang diperoleh dengan skala > 3,52 yaitu, untuk validator I rata-rata total mencapai 3,05 dan validator II mencapai 3,66 .

\section{Keterlaksanaan RPP}

Setiap kegiatan pembelajaran dilakukan observasi untuk mengamati keterlaksanaan rencana pelaksanaan pembelajaran (RPP). Adapun data keterlaksanaan pembelajaran pada kelas eksperimen dan kontrol disajikan padaTabel 6.

Tabel 6. Data keterlaksanaan RPP setiap pertemuan pada kelompok eksperimen dan kontrol

\begin{tabular}{llcccc}
\hline No & \multicolumn{1}{c}{ Aspek Pengukuran } & \multicolumn{2}{c}{ Kelas Eksperimen } & \multicolumn{2}{c}{ Kelas Kontrol } \\
\cline { 3 - 6 } & & P I & P II & P I & P II \\
\hline 1 & Jumlah langkah seluruhnya & 12 & 12 & 7 & 7 \\
2 & Jumlah langkah yang terlaksana & 12 & 12 & 6 & 5 \\
3 & Jumlah langkah yang tidak terlaksana & 0 & 0 & 1 & 2 \\
4 & Persentase & $100 \%$ & $100 \%$ & $85,7 \%$ & $71,4 \%$ \\
5 & Kategori & Sangat Baik & Sangat Baik & Baik & Baik \\
\hline
\end{tabular}

Berdasarkan Tabel 6, diketahui bahwa keterlaksanaan pembelajaran pada kelompok ekperimen pada pertemuan 1 dan 2 berjalan 100\% dengan ketegori sangat baik. Sedangkan persentase keterlaksanaan pembelajaran pada kelompok kontrol di pertemuan 1 sebesar $85,7 \%$ dengan kategori baik dan pertemuan 2 sebesar $71,4 \%$ dengan kategori baik. Hal ini membuktikan bahwa pembelajaran di kelompok eksperimen dan kontrol sudah berlangsung dengan baik.

\section{Data Keterampilan Sosial}

Data keterampilan sosial siswa kelompok eksperimen dan kelompok kontrol diperoleh melalu observasi pada saat pembelajaran berlangsung. Adapun data keterampilan sosial disajikan pada Tabel 7.

Tabel 7. Data keterampilan sosial siswa kelas eksperimen dan kontrol

\begin{tabular}{cccccc}
\hline \multirow{2}{*}{ Kelas } & \multirow{2}{*}{ Kelompok } & \multicolumn{4}{c}{ Kelas Eksperimen } \\
\cline { 3 - 6 } & & P I (\%) & Kategori & P II (\%) & Kategori \\
\hline Eksperimen & I & 82 & Baik & 70 & Baik \\
& II & 64 & Kurang Baik & 70 & Baik \\
& III & 70 & Baik & 76 & Baik \\
& IV & 64 & Kurang Baik & 76 & Baik \\
& V & 76 & Baik & 70 & Baik \\
& Rata-rata & 71,2 & Baik & 72,4 & Baik \\
\hline Kontrol & & 70 & Baik & 64 & Kurang Baik \\
\hline
\end{tabular}

Berdasarkan Tabel 7, diketahui bahwa keterampilan sosial siswa pada kelompok eksperimen pada pertemuan 1 adalah kelompok 1 sebesar $82 \%$ dengan kategori baik, kelompok II 64\% dengan kategori kurang baik, kelompok III 70\% dengan kategori baik, kelompok IV 64\% dengan kategori kurang baik, dan kelompok V 76\% dengan kategori baik, dan pada pertemuan 2 adalah kelompok 1 sebesar $70 \%$ dengan kategori baik, kelompok II $70 \%$ dengan kategori baik, kelompok III 76\% kategori baik, kelompok IV 76\% dengan kategori baik, dan kelompok V $70 \%$ dengan kategori baik. Sedangkan keterampilan sosial siswa pada kelas kontrol pertemuan 1 sebesar $70 \%$ dengan kategori baik dan pertemuan II sebesar $64 \%$ dengan kategori kurang baik.

\section{Hasil Belajar Kognitif Siswa}

Data hasil belajar dikumpulkan menggunakan instrument tes berbentuk pilihan ganda sebanyak 20 butir dan diberikan kepada siswa diakhir pembelajaran (post test). Adapun data hasil belajar kelompok ekperimen dan kontrol disajikan pada Tabel 8 yang menunjukkan data hasil belajar kognitif siswa pada kelompok eksperimen memperoleh nilai tertinggi sebesar 80 , sedangkan nilai terendah sebesar 35 dengan rata-rata sebesar 63,75. Sedangkan pada 
kelompok kontrol memperoleh nilai tertinggi sebesar 65 dan nilai terendah sebesar 30 dengan rata-rata sebesar 50,52.

Tabel 8. Hasil Belajar Kognitif Siswa kelompok Eksperimen dan kelompok Kontrol

\begin{tabular}{lcccc}
\hline \multicolumn{1}{c}{ Kelas } & Jumlah Siswa & Nilai Tertinggi & Nilai Terendah & Rata-Rata Nilai \\
\hline Eksperimen & 28 & 80 & 35 & 63,75 \\
Kontrol & 29 & 65 & 30 & 50,52 \\
\hline
\end{tabular}

Data hasil belajar siswa dianalisis normalitas dan homogenitas sebelum pengujian hipotesis. Tabel 9 menunjukkan hasil perhitungan di mana $X^{2}{ }_{\text {hitung }}=12,208$ sedangkan $X^{2}{ }_{\text {hitung }}$ pada taraf signifikan $5 \%$ dengan $\mathrm{dk}=6$ diperoleh $X^{2}{ }_{\text {tabel }}=14,06$ karena $X^{2}{ }_{\text {hitung }}<X^{2}{ }_{\text {tabel, }}$, maka hasil posttest kelompok eksperimen (KE) dan kelompok control (KK) dinyatakan terdistribusi normal

Tabel 9. Hasil Uji Normalitas data KK dan KE

\begin{tabular}{cccc}
\hline Variabel & $\mathbf{X}^{2}$ hitung & $\mathbf{X}^{2}$ tabel & Uji Normalitas \\
\hline $\begin{array}{l}\text { Posttest hasil belajar KE } \\
\text { Posttest hasil belajar KK }\end{array}$ & 12,208 & 14,06 & Terdistribusi Normal \\
\hline
\end{tabular}

Uji homogenitas bertujuan untuk mengetahui data kelompok eksperimen dan kelompok kontrol berasal dari sampel yang sama (homogen). Uji homogenitas data penelitian (Table 10) menunjukkan bahwa varians pada kelompok eksperimen 109729,68 yang menunjukkan varians terbesar dan varians pada kelompok control 71455,76 yang menunjukkan varians terkecil. Berdasarkan hasil perhitungan pada taraf signifikan $5 \%$ diperoleh $\mathrm{F}_{\text {hitung }}=1,53$ dan $\mathrm{F}_{\text {tabel }}=1,93$ atau $1,53<1,93$, maka kedua kelas tersebut berasal dari sampel yang sama.

Tabel 10. Hasil uji homogenitas post-test kelompok eksperimen dan kontrol

\begin{tabular}{ccccccc}
\hline No & Kelas & $\sum$ Siswa & Nilai rata-rata & Varians $\boldsymbol{S}^{\mathbf{2}}$ & $\mathbf{F}_{\text {hitung }}$ & $\mathbf{F}_{\text {tabel }}$ \\
\hline 1 & Eksperimen & 28 & 63,75 & 109729,68 & \multirow{2}{*}{1,53} & \multirow{2}{*}{1,93} \\
2 & Kontrol & 29 & 50,52 & 71455,76 & & \\
\hline
\end{tabular}

Data hasil penelitian dinyatakan homogen dan terdistribusi normal sehingga pengujian hipotesis menggunakan persamaan t-test polled Varians (Persamaan 7). Adapun ringkasan hasil pengujian hipotesis disajikan pada Tabel 11 yang menunjukkan bahwa hipotesis yang diajukan dalam penelitian ini memiliki harga thitung lebih besar dari pada tabel pada taraf signifikan $5 \%$ dengan $\mathrm{dk}=55$ (thitung $>t_{\text {tabel }}=1,53<1,93$ ). Dengan demikian, dapat disimpulkan bahwa Ho diterima, artinya tidak ada pengaruh model pembelajaran kooperatif tipe STAD (Student Teams Achievement Division) terhadap keterampilan sosial dan hasil belajar kognitif siswa.

Tabel 11. Ringkasan Hasil Uji Hipotesis

\begin{tabular}{lll}
\hline \multicolumn{1}{c}{ Keterangan } & Hasil \\
\hline pNilai rata-rata selisih kelas Eksperimen $\left(\bar{x}_{1}\right)$ & 63,75 \\
Nilai rata-rata selisih kelas Kontrol $\left(\bar{x}_{2}{ }^{2}\right)$ & 50,52 \\
Varians deviasi kelas eksperimen $\left(\mathrm{S}_{1}{ }^{2}\right)$ & 109729,68 \\
Varians deviasi kelas kontrol $\left(\mathrm{S}_{2}{ }^{2}\right)$ & 71455,76 \\
Jumlah siswa kelas Eksperimen $\left(\mathrm{n}_{1}\right)$ & 28 \\
Jumlah siswa kelas Kontrol $\left(\mathrm{n}_{2}\right)$ & 29 \\
thitung $(\mathrm{t}$-test) & 1,53 \\
tabel pada taraf signifikan $5 \%$ untuk dk $=55$ & 1,93 \\
Keputusan & $\mathrm{H}_{\mathrm{o}}$ diterima \\
\hline
\end{tabular}

Penggunaan model pembelajaran kooperatif tipe STAD dalam pembelajaran biologi juga dapat menjadi bentuk keterampilan sosial siswa yaitu cara siswa untuk saling berkomunikasi melakukan interaksi antara teman sebaya yang biasa diberikan untuk memunculkan timbal balik positif dari proses pembelajaran yang sedang berlangsung sehingga semua yang disampaikan oleh guru tidak hanya didengar saja namun dapat dipahami, dan soal-soal yang diberikan oleh guru dapat diselesaikan, selain itu juga siswa dapat meningkatkan interaksi dan kerja sama dengan teman sekelompok, teman sekelas dan juga guru. 
Berdasarkan hasil observasi selama proses pembelajaran dengan model pembelajaran Kooperatif Tipe STAD pada kelas eksperimen dan pembelajaran konvensional, keterampilan sosial siswa diketahui berkategori baik, namun skor kelompok eksperimen ditemukan lebih baik dari kelompok control (mean $=71,8 \%$ vs. mean $=67 \%$ ). Siswa dalam pembelajaran kooperatif tipe STAD dibelajarkan untuk saling membantu dalam mengerjakan tugas-tugas terstruktur, sehingga dapat menumbuhkan keterampilan social (Nurmila et al., 2019), selain itu, model pembelajaran ini juga dijelaskan dapat menumbuhkan minat belajar siswa (Laa et al., 2017) karena materi pembelajaran lebih mudah dipahami, inovatif, kreatif, menyenangkan, dan tidak mudah merasa bosan (Hasanah et al., 2014).

Hasil penelitian menunjukkan skor rata-rata hasil belajar kognitif siswa kelompok eksperimen lebih tinggi dibandingkan kelompok kontrol (mean $=63,75$ vs. mean $=50,52$ ), namun secara statistic ditemukan tidak berbeda secara signifikan $\left(t_{\text {hitung }}=1,53<t_{\text {tabel }}=\right.$ 1,93). Hasil penelitian ini kontradiktif terhadap hasil penelitian terdahulu yang menemukan model pembelajaran kooperatif tipe STAD berpengaruh secara signifikan terhadap hasil belajar (Kansil \& Suriani, 2020; Nuraeni et al., 2020) dan motivasi belajar siswa (Marfani et al., 2017).

\section{KESIMPULAN}

Berdasarkan hasil penelitian yang telah dilakukan dapat disimpulkan bahwa keterampilan social siswa pada kelompok eksperimen dan kelompok control berkategori baik namun secara deskriptif kelompok eksperimen mendapatkan skor yang lebih tinggi (mean= $71,8 \%$ vs. mean $=67 \%$ ). Secara statistic, $\mathrm{t}$ hitung $=1,242$ dengan $\mathrm{db}=55$ pada taraf signifikan $5 \%$ maka $t$ tabel $=1,671$. Ternyata $t$ nitung lebih besar dari $t$ tabel atau $t$ hitung $=1,53<t$ tabel $=1,93$, sehingga dengan demikian $\mathrm{H}_{\circ}$ diterima sehingga dapat dinyatakan bahwa tidak ada pengaruh model pembelajaran kooperatif tipe STAD terhadap keterampilan sosial dan hasil belajar kognitif siswa.

\section{REKOMENDASI}

Berdasarkan kesimpulan di atas, saran dalam penelitian ini adalah proses belajar mengajar hendaknya menggunakan model pembelajaran yang sesuai dengan materi yang akan diajarkan agar siswa tidak cepat merasa bosan dalam proses pembelajaran. Penelitian selanjutnya hendaknya lebih mempertimbangkan waktu. Model pembelajaaran kooperatif tipe STAD dapat menjadi pertimbangan untuk digunakan, meskipun secara statistic dinyatakan tidak berpengaruh, namun secara deskriptif menunjukkan potensi untuk meningkatkan keterampilan social dan hasil belajar kognitif siswa.

\section{DAFTAR PUSTAKA}

Alfiani, D. A., \& Sopiyani, S. (2014). Pengaruh model pembelajaran cooperative learning tipe student teams achievement division (stad) terhadap hasil belajar ipa siswa kelas $v$ di sd negeri 1 tersana kecamatan pabedilan kabupaten Cirebon. Al Ibtida: Jurnal Pendidikan Guru MI, 1(1), Article 1. https://doi.org/10.24235/al.ibtida.snj.v1i1.459

Arifin, N. R. (2018). Pengaruh Model Pembelajaran Kooperatif Tipe Student Team Achievement Division (STAD) Terhadap Kemampuan Berpikir Kritis Siswa (Studi Eksperimen pada Mata Pelajaran Ekonomi Kelas XI SMA Informatika Ciamis). Jurnal Edukasi (Ekonomi, Pendidikan dan Akuntansi), 6(1), 251-262. https://doi.org/10.25157/je.v6i1.1701

Arikunto, S. (2013). Dasar-dasar Evaluasi Pendidikan (edisi 2). Bumi Aksara. https://ecampusfip.umj.ac.id/pustaka_umj/main/item/14939

Asy'ari, M., Hidayat, S., \& Muhali, M. (2019). Prototipe buku ajar fisika dasar reflektif-integratif berbasis problem solving untuk meningkatkan pengetahuan metakognisi. Jurnal Inovasi Pendidikan IPA, 5(2), Article 2. https://doi.org/10.21831/jipi.v5i2.27089

Hasanah, H., Suyidno, S., \& Wati, M. (2014). Pengaruh Pembelajaran Kooperatif Tipe Student Team Achievement Division (STAD) Dengan Latihan Berstruktur Terhadap Hasil Belajar Siswa. Berkala Ilmiah Pendidikan Fisika, 2(1), 47-54. https://doi.org/10.20527/bipf.v2i1.817 
Kansil, K. S. M., \& Suriani, N. W. (2020). Pengaruh Model Pembelajaran Kooperatif Tipe STAD (Student Teams Achievement Division) Terhadap Hasil Belajar Siswa Materi Ciri-Ciri Makhluk Hidup. SCIENING: Science Learning Journal, 1(1), 16-19. https://doi.org/10.53682/slj.v1i1.31

Kemendikbud. (2014). Permendikbud No.103 Tahun 2014: Tentang Pembelajaran Pada Pendidikan Dasar dan Pendidikan Menengah - KomKat KWI. Kemendikbud. https://komkat-kwi.org/2015/08/18/permendikbud-no-103-tahun-2014-tentangpembelajaran-pada-pendidikan-dasar-dan-pendidikan-menengah/

Kholin, M., Meurs, J. A., Blickle, G., Wihler, A., Ewen, C., \& Momm, T. D. (2016). Refining the Openness-Performance Relationship: Construct Specificity, Contextualization, Social Skill, and the Combination of Trait Self- and Other-Ratings. Journal of Personality Assessment, 98(3), 277-288. https://doi.org/10.1080/00223891.2015.1076430

Laa, N., Winata, H., \& Meilani, R. I. (2017). Pengaruh model pembelajaran kooperatif tipe student teams achievement division terhadap minat belajar siswa. Jurnal Pendidikan Manajemen Perkantoran (JPManper), 2(2), 251-260. https://doi.org/10.17509/jpm.v2i2.8115

Marfani, M., Fatmawati, A., \& Primawati, S. N. (2017). Pengaruh model pembelajaran kooperatif tipe stad (student team achievement division) di padu nht (numbered heads together) terhadap motivasi dan hasil belajar kognitif siswa. Bioscientist : Jurnal IImiah Biologi, 5(1), 13-21. https://doi.org/10.33394/bjib.v5i1.174

Marheni, N. K., Jampel, I. N., \& Suwatra, I. I. W. (2020). Pengaruh Model Pembelajaran Kooperatif Tipe (STAD) Terhadap Sikap Sosial dan Hasil Belajar IPA. Jurnal Penelitian Dan Pengembangan Pendidikan, 4(3), 351-361. https://doi.org/10.23887/jppp.v4i3.27414

Maryani, E. (2011). Pengembangan program pembelajaran ips untuk peningkatan keterampilan sosial. Alfabeta.

Muhali, M., Sukaisih, R., \& Asy'ari, M. (2020). Implementasi model reflective-metacognitive learning untuk meningkatkan kemampuan berpikir kritis, keterampilan metakognisi dan kesadaran metakognisi. Empiricism Journal, 1(2), 75-95. https://doi.org/10.36312/ej.v1i2.337

Ningrat, H. K. (2018). Penerapan pembelajaran kooperatif tipe stad dan pengaruhnya terhadap hasil belajar kognitif dan kecakapan sosial ditinjau dari sikap ilmiah peserta didik. Jurnal Tatsqif, 16(2), 126-143. https://doi.org/10.20414/jtq.v16i2.307

Nuraeni, S. E., Afghohani, A., \& Exacta, A. P. (2020). Pengaruh model pembelajaran kooperatif tipe stad terhadap prestasi belajar matematika siswa sma. Jurnal Pendidikan, Sains Sosial, Dan Agama, 6(2), 1-5. https://doi.org/10.53565/pssa.v6i2.180

Nurmila, W. O., Kadir, K., Sudia, M., \& Prajono, R. (2019). Pengaruh Model Pembelajaran Kooperatif Tipe Student Team Achievement Division Terhadap Hasil Belajar Matematika Siswa Kelas VII SMP Kesehatan Mandonga. Jurnal Pendidikan Matematika, 10(1), 112-123. https://doi.org/10.36709/jpm.v10i1.5649

Prasetyo, M. M. (2020). Pengaruh penerapan model pembelajaran kooperatif tipe stad dipadukan dengan strategi inkuiri terbimbing terhadap aktivitas dan hasil belajar mahasiswa STKIP pembangunan Indonesia. Binomial, 3(2), 131-147. https://doi.org/10.46918/binomial.v3i2.666

Putri, N. P. I. A., Pujani, N. M., \& Devi, N. L. P. L. (2019). Pengaruh model pembelajaran kooperatif tipe think pair share terhadap keterampilan sosial dan prestasi belajar siswa smp. Jurnal Pendidikan Dan Pembelajaran Sains Indonesia (JPPSI), 2(2), 92-103. https://doi.org/10.23887/jppsi.v2i2.19377.g11450

Qurtubhi, W. M. (2017). Effect of cooperative learning model type think pair and share (tps) on student cooperation (quasi experiments on social studies learning class vii in 1 Cikajang junior high school). International Journal Pedagogy of Social Studies, 2(2), 53-58. https://doi.org/10.17509/ijposs.v2i2.10165

Rusman. (2011). Model-model pembelajaran: Mengembangkan profesionalisme guru. Rajawali Press.

Sari, N., Lestari, R., \& Dahlia, D. (2015). Pengaruh Model Pembelajaran Kooperatif Tipe Student Team Achievement Division (Stad) Berbantuan Media Gambar Terhadap 
Keterampilan Proses Sains Dan Hasil Belajar Siswa Kelas XI Mia SMA N 1 Bangun Purba Tahun Pembelajaran 2014/2015 [Journal:eArticle, Universitas Pasir Pengaraian]. In Jurnal Mahasiswa Prodi Biologi UPP (Vol. 1, Issue 1, p. 111100). https://www.neliti.com/id/publications/111100/

Scott, C. (2015). The Futures of Learning 2: What Kind of Learning for the 21st Century? Education Research and Foresight Working Papers, UNESCO. https://www.semanticscholar.org/paper/The-Futures-of-Learning-2-\%3A-What-Kindof-Learning-Scott/2d6f8927dce32ce550b1c91613583c1b76b110ae

Sugiyono. (2019). Metode Penelitian Kuantitatif, Kualitatif, dan R\&D. Alfabeta.

Tendrita, M., \& Sari, A. P. P. (2020). Penerapan Model Pembelajaran Kooperatif Tipe Student Team Achievement Division (STAD) Dipadu RQA Berbasis Lesson Study untuk Meningkatkan Motivasi Belajar dan Kemampuan Komunikasi Mahasiswa Pendidikan Biologi Universitas Negeri Malang. Bioedusiana: Jurnal Pendidikan Biologi, 5(1), 1. https://doi.org/10.34289/bioed.v5i1.1427 